\title{
„Wieś Radomska” 2018, t. 11
}

\author{
“Wieś Radomska", Vol. 11, 2018
}

„Wieś Radomska” stanowi kontynuację (z zachowaniem numeracji tomów) "Zeszytów Naukowych Muzeum Wsi Radomskiej” ukazujących się w latach 1986-1990. Periodyk - zarówno pod dawnym, jak i obecnym tytułem - stanowi bogate źródło opracowań i dokumentów dotyczących dziedzictwa kultury ludowej, historii oraz zjawisk społeczno-gospodarczych Radomskiego - regionu tradycyjnie lokowanego w widłach Wisły i Pilicy, obejmującego obszar pogranicza dzisiejszych województw mazowieckiego, świętokrzyskiego i łódzkiego. Ciekawym subregionem o charakterze przyrodniczo-kulturowym, któremu poświęca się na łamach „Wsi Radomskiej” sporo miejsca, jest także Puszcza Kozienicka określana w literaturze jako „trzon Radomskiego".

Wydawcą czasopisma jest Muzeum Wsi Radomskiej (MWR), które w 2016 r. obchodziło jubileusz $40-$ lecia istnienia. Obecnie to instytucja kultury, której organizatorem jest Samorząd Województwa Mazowieckiego. Placówka kojarzona jest przede wszystkim z ekspozycją na wolnym powietrzu - skansenem zlokalizowanym na przedmieściach Radomia przy ul. Szydłowieckiej. MWR posiada także Oddział w Przysusze - miejscowości bliskiej sercu każdego etnografa i regionalisty. Tu bowiem 22 II I8I4 r. urodził się Oskar Kolberg, który jest patronem oddziału muzeum. Jego imię nosi również wręczana tu rokrocznie nagroda będąca najważniejszym w Polsce wyróżnieniem za działania twórcze, artystyczne, naukowe, wspierające oraz popularyzujące tradycyjną kulturę regionalną.

Jedenasty tom otwiera dział ARTYKUŁY, a w nim tekst Artura Gawła z Podlaskiego Muzeum Kultury Ludowej Zwyczaje i wierzenia zwiqzane z jesienna orka i siewem zbóż ozimych na Podlasiu. Autor mierzy się z problematyką, z którą tradycyjnie, choć nieco stereotypowo, kojarzy

I J. Górska-Streicher, Rzemiosto na terenie Puszczy Kozienickiej w okresie Polski Ludowej, „Wieś Radomska” 2016, t. I0, s. 156. 
się etnografów. Przybliża szereg praktyk, głównie o charakterze religijno-magicznym, związanych z wysiewem zbóż ozimych. Sięga przy tym do rozległej literatury etnograficznej oraz materiałów z badań terenowych. Przywołuje wiele zapomnianych lub używanych jeszcze przysłów. Sporo tu znakomitych przykładów potwierdzających ugruntowane już koncep$\mathrm{cje}^{2}$. Szereg indywidualnych działań polowych posiadało tradycyjną formę. W powszechnej opinii zaniechanie lub zignorowanie pewnych zasad pociągało za sobą konsekwencje niekorzystne dla całej społeczności, podlegało zatem kontroli i sankcji. Dotyczyło to np. zakazu orki w czasie adwentu, ale także obowiązku wykonania określonych działań magicznych związanych z siewem żyta. W różnego rodzaju działaniach wyeksponowana była rola autorytetów i znaczenie międzypokoleniowego przekazu. Przestrzegano zasady, że zarówno jesienną orkę jak i siew rozpoczynał najbardziej szanowany we wsi gospodarz, zaś młodsi starali się naśladować jego sposób pracy. Bacznie obserwowano przyrodę, a najodpowiedniejszą porę rozmaitych czynności wyznaczano, uwzględniając nie tylko parametry takie jak temperatura czy wilgotność, ale także stopień wegetacji rozmaitych roślin lub obfitość uzyskanych latem plonów. A. Gawła - jako wytrawnego muzealnika - interesują także technikalia i kontekst kultury materialnej. Wykracza, z dobrym zresztą skutkiem, poza tytułowe zwyczaje i wierzenia, przybliżając podstawowe informacje dotyczące np. słomianych koszy (siewieniek) i lnianych płacht (fartuchów), w które wyposażeni byli idący w pole siewcy.

Wątpliwość budzi ostatnie zdanie, w którym Autor stwierdza, że „współcześnie (...) zarówno orka jak i siew stały się pracami rolniczymi, których powodzenie zależy tylko i wyłącznie od technicznych możliwości rolnika” (s. 17). Trudno się z tym zgodzić. Sukces zapewnia dziś specjalistyczna wiedza, ale nadal liczą się całkiem tradycyjne elementy, takie jak doświadczenie, pracowitość, znajomość specyfiki własnego areału, baczna obserwacja przyrody i znajomość jej prawideł. Gdyby pewien etnolog z Uniwersytetu Łódzkiego pogrążony w lekturze „Wsi Radomskiej” zabrał się do jesiennych prac polowych wyposażony w najdoskonalszy sprzęt, i tak nic by z tego nie wyszło.

Małgorzata Imiołek z Muzeum Wsi Kieleckiej jest Autorką napisanego $\mathrm{z}$ dużym znawstwem artykułu Rola budulca kamiennego w ksztattowaniu specyfiki budownictwa chtopskiego na wybranych terenach Kielecczyzny od potowy XIX wieku do lat so. XX wieku. Zaprezentowany tu material to efekt

2 Por. m.in.: K. Dobrowolski, Chtopska kultura tradycyjna. (Próba teoretycznego zarysu na podstawie materiatów źródtowych XIX i XX w. z potudniowej Matopolski), „Etnografia Polska”, I958, t. I, s. 19-52; R. Tomicki, Tradycja i jej znaczenie w kulturze chtopskiej, „Etnografia Polska” 1973, t. XVII, z. 2, s. 4I-58. 
badań terenowych prowadzonych na przestrzeni kilkunastu lat (1999-2015). Wykazały one, że na sporych obszarach Kielecczyzny (powiaty: kielecki, buski, jędrzejowski, kazimierski, pińczowski i włoszczowski) kamień stanowi wyróżnik lokalny budownictwa chłopskiego. M. Imiołek unika przy tym nieścisłego i dyskusyjnego pojęcia „typu regionalnego”. Zwraca też uwagę, że tradycyjna opozycja drewniane - murowane okazuje się niewystarczająca. W przypadku obszarów położonych na południowy-zachód od Kielc zasadniczym wyróżnikiem kształtującym specyfikę krajobrazu architektonicznego wsi był budulec kamienny. Pozostałe cechy, zarówno formalne jak i typologiczne, nie odgrywały tu roli czynnika charakteryzującego. Wybór takiego właśnie materiału podyktowany był zarówno warunkami naturalnymi (obfitość surowców skalnych, wylesienie), jak i względami antropogenicznymi (sytuacja społeczno-gospodarcza, lokalne możliwości wykonawcze, infrastruktura drogowa, tradycja). Autorka szczegółowo analizuje każdy z tych czynników, zarówno w kontekście czasowym, jak i przestrzennym. Druga część artykułu to zbiorcza analiza pod względem formalnym i materiałowym 153 kamiennych obiektów mieszkalnych powstałych między latami 80. XIX w. a 50. XX w. odnotowanych w 29 wsiach. Cenne i przekonujące okazują się argumenty, którymi M. Imiołek posługuje się dla wyjaśnienia stosunkowo późnego „awansu” kamienia jako budulca. Dołączone do artykułu mapy ukazują, iż zasięg chłopskiego budownictwa kamiennego na Kielecczyźnie od połowy XIX w. systematycznie się powiększał, a przecież bylibyśmy skłonni kamień uznać za najbardziej „pradawny” materiał. Wypadałoby zatem uznać, że o „karierze” tego budulca zadecydowało wylesienie. Autorka zwraca jednak uwagę na szereg innych okoliczności. Przede wszystkim przypomina, że budownictwo chłopskie do czasu reform uwłaszczeniowych w sensie inwestycyjnym było chłopskim tylko z nazwy. W realiach pańszczyźnianych to właściciele, a zatem szlachta, decydowali o budowie i konserwacji obiektów włościańskich. Z czasem sporego znaczenia nabrały też stosowane przepisy i nakazy urzędowe. W tym kontekście prosta, choć logiczna zasada głosząca, iż w przypadku budownictwa chłopskiego o użytym materiale decyduje jego dostępność, zaczęła się na szerszą skalę sprawdzać dopiero w drugiej pol. XIX w. Wówczas bowiem wolny chłop musiał samodzielnie decydować o zabudowie i pozyskiwać potrzebny na nią materiał. Obszerny artykuł M. Imiołek godny jest polecenia wszystkim zainteresowanym problematyką budownictwa wiejskiego.

Jolanta Dragan reprezentująca Muzeum Kultury Ludowej w Kolbuszowej analizuje Znaczenie lnu w tradycyjnej kulturze środkowej Polski. Len to jedna z pierwszych roślin udomowionych przez człowieka. Jej znaczenie praktyczne, magiczne, symboliczne, ekonomiczne było do niedawnych 
czasów ogromne. W realiach europejskich, w licznych opracowaniach historycznych, terminy takie jak tkanina czy płótno funkcjonują wręcz jako synonimy materiału uzyskanego z włókna lnianego. Warto pamiętać, że len to także siemię, z którego przez stulecia tłoczono olej, wykorzystywano je także w celach leczniczych. Dragan przybliża wybrane zagadnienia związane z uprawą i obróbką lnu, koncentrując się jednak na kwestiach kulturowych. Motywy „Iniane” obecne są w licznych tekstach folklorystycznych towarzyszących wielu momentom tradycyjnego roku obrzędowego oraz działaniom o charakterze rolniczym. Zwracają uwagę powszechne i ciekawe zabiegi, szczególnie w ramach tzw. magii sympatycznej (podobne rodzi podobne), mające zapewnić urodzaj lnu. Podskoki taneczne w trakcie zapustów, obserwacja długości lodowych sopli czy też zakaz kładzenia się gospodarzy w Wielkanoc (aby len w trakcie wegetacji nie zachowywał się podobnie) są tego znakomitymi przykładami. Len, narzędzia służące jego obróbce, a także wyroby wykonane z włókna tej rośliny stawały się często atrybutami osób mediacyjnych - dzieci przed chrztem, kobiet w ciąży, młodych w czasie wesela. Stanowiły także emblemat osób pełniących określone funkcje przy rozmaitych obrzędach. Jeśli uwzględnimy także fakt, że na przestrzeni setek lat zmarłych grzebano w specjalnych koszulach lub lnianych całunach, wypada stwierdzić, że len towarzyszył człowiekowi od kolebki aż po grób. W dalszej kolejności Autorka omawia leczniczą oraz magiczno-apotropeiczną funkcję lnu, w ramach której miał on chronić człowieka przed mocami demonicznymi.

Podsumowując, artykuł stanowi udaną próbę ukazania znaczenia, roli i funkcji lnu, choć Autorka sama zaznacza, że prezentuje zagadnienie, odnosząc się jedynie do „wybranych kontekstów kultury tradycyjnej” (ss. 57, 59) $\mathrm{i}$,w bardzo skrótowej formie” (s. 84). Drobne wątpliwości budzi tytułowa kategoria środkowej Polski jako obszaru, którego dotyczą przemyślenia i przykłady. Oczywiście samo jej użycie jest zasadne, problem dotyczy precyzji delimitacji. J. Dragan korzysta z propozycji Ireny Lechowej (artykuł z 1976 r.), w której jest mowa o obszarze województwa łódzkiego sprzed reformy administracyjnej roku 1975 (s. 57), jednocześnie kreśli nieco szerszy obszar sięgający od powiatu kaliskiego na zachodzie, po płocki na północy, warszawski zachodni na wschodzie i pajęczański na południu (s. 57, przypis I). Pewien dysonans wywołuje także wykorzystana w artykule ikonografia, na którą składają się fotografie z archiwum Muzeum Kultury Ludowej w Kolbuszowej - zatem miejscowości leżącej z dala od tytułowego obszaru.

Dział MATERIA£Y wypełnia tekst przygotowany przez Katarzynę Markiewicz (Muzeum im. Oskara Kolberga w Przysusze, o. Muzeum Wsi Radomskiej) Wspomnienia Konopczanek z Modlnicyo Oskarze Kolbergu. W 2004 r. 
archiwalia MWR wzbogaciły się o zespół materiałów związanych z O. Kolbergiem gromadzonych od lat 30. XX w. przez zmarłą w 1987 r. Marię Turczynowicz. Wśród różnorodnych dokumentów, które trafily do muzealnych zbiorów, znalazły się wspomnienia przedstawicielek rodziny Konopków. $\mathrm{Z}$ rodziną tą - kultywującą niepodległościowe tradycje i posiadającą w drugiej poł. XIX w. szereg majątków w pobliżu Krakowa - utrzymywał ścisłe kontakty O. Kolberg, który kilkanaście lat mieszkał w należącym do Konopków dworze w Modlnicy. Opracowane przez K. Markiewicz teksty wspomnieniowe o wybitnym ludoznawcy zostały napisane przez Antoninę Konopczankę (1827-1905) oraz jej dwie bratanice: Justynę Konopczankę (I862-1957) i Michalinę z Konopków Paszkiewiczową (ur. 1860). Najobszerniejsze, najciekawsze i najcenniejsze są wspomnienia Antoniny, która była reprezentantką pokolenia O. Kolberga - młodszą siostrą Józefa Konopki (I8I 8-1880), z którym etnograf odbywał pierwsze wyprawy terenowe w okolice Warszawy. Spisane wiele lat po śmierci O. Kolberga wspomnienia kobiet, które znały go osobiście, dostarczają wielu informacji o jego życiu w Modlnicy, przyzwyczajeniach, charakterze (niezwykle łagodnym), relacjach z innymi. Warto - jako ciekawostkę rzucającą nieco światła na styl pracy i naturę autora $L u d u$ - zacytować fragment wspomnień Antoniny na temat figli, jakie płatali mu młodzi ludzie: „Znowu inni pomagający mu szczerze w zbiorze materiałów - podali swojego utworu niektóre krakowiaki, powieści na sposób gminny ułożone, czyli je od prawdziwie ludowych odróżnić zdoła. Myśleli, że się pozna na robocie - gdzie tam - nie tylko się nie poznał - ale chciwie pochwyciwszy nie puścił więcej i drukował. Już on się nie pytał - co i jakie od kogo dostał, bo mu szło o to głównie, żeby jak najobszerniejsze mieć zbiory, jak mawiał waryjanty, które układał za rubrykami, numerami i odpowiednio klasyfikował. $\mathrm{O}$ innych dziełach nie wiem, lecz w krakowskich wiem doskonale jak się co urządzało" (s. 103). Dobrze się stało, że tak cenny materiał został przez K. Markiewicz naukowo opracowany i udostępniony.

Tekst Hanny Rybickiej Cieśla Józef Neuman (1869-1949) i jego rodzina umieszczono w dziale RELACJE I wSPOMNIENIA. To klasyczny materiał biograficzno-wspomnieniowy. Autorka - zamieszkała w Warszawie dr nauk rolniczych - kreśli biogramy ośmiorga członków swojej rodziny, której męscy przedstawiciele parali się w Radomiu ciesielstwem (m.in. przy budowach i remontach kościołów). Wzmianki o cieślach Neumanach znajdują się w drukowanych opracowaniach na temat Radomia, ale H. Rybicka korzysta przede wszystkich z dokumentów rodzinnych, przekazów ustnych i własnych wspomnień lub notatek. Tytułowy przedstawiciel rodu, Józef, był Jej dziadkiem. Jemu też oraz jego żonie Helenie (z domu Gorczyckiej) 
Autorka poświęca najwięcej miejsca. Dopełnieniem biogramów jest część wspomnieniowa. Ten ciekawy tekst poświęcony jest przede wszystkim posesji Neumanów przy ul. Kozienickiej w Radomiu (dom z oficynami i rozległy ogród dziś już nie istnieją) oraz jej mieszkańcom, przedstawicielom trzech pokoleń. Autorka wspomnień z wielką dokładnością odtwarza układ pomieszczeń, wyposażenie domu oraz warsztatu Józefa. Opisuje sad i rosnące tam drzewa. Tę przestrzeń - wówczas na przedmieściach Radomia - wypełniała praca spokojnego dziadka, krzątanina charyzmatycznej babci, gwar dziatwy. Szczególnie cenne wydają się fragmenty opisujące codzienność okupacyjną i życie okolicy w tym trudnym okresie. Nie brak tu wątków konspiracyjnych, jako że ojciec Autorki, Józef Roman Rybicki, objął w lutym I94I r. funkcję komendanta Okręgu Kielce-Radom Tajnej Organizacji Wojskowej, a w mieszkaniu dziadków od I944 r. odbywało się tajne nauczanie. To wartościowy materiał dla każdego radomskiego regionalisty.

EDUKACJA, to dział wypełniony obszernym materiałem Grzegorza Miliszkiewicza z Muzeum Wsi Lubelskiej noszącym tytuł Zostanę kowalem. Tekst podstawowy do dziatań muzealnych w obrębie ekspozycjiskansenowskiej: zajęć edukacyjnych, narracji i prezentacji przewodnickich oraz parateatru. Autor jest doświadczonym edukatorem, orędownikiem rzetelnego i uczciwego prezentowania treści programowych zajęć edukacyjnych przez placówki muzealne ${ }^{3}$. Miliszkiewicz podkreśla pożytki płynące z prób odtworzenia na terenie muzeów na otwartym powietrzu wydarzeń z dawnego życia codziennego. Co istotne, Autor ten od lat próby takie z powodzeniem podejmuje w lubelskim skansenie. Prezentowany na łamach „Wsi Radomskiej” tekst jest propozycją szczególną. G. Miliszkiewicz wychodzi z założenia, że z uwagi na ubogą ilość wypowiedzi osób żyjących kilka pokoleń wcześniej na temat ich życia codziennego, warto sięgnąć po tematyczną i narracyjną baśń, która grana w przestrzeni ekspozycji i w środowisku zabytków przez gości pod opieką muzealnika może odnieść lepszy efekt edukacyjny niż tradycyjna narracja przewodnicka. Baśń Zostanę kowalem, której tekst poetycki wraz z komentarzami udostępnia nam G. Miliszkiewicz, to propozycja bezpośredniego, interaktywnego kontaktu muzealnika ze zwiedzającymi. Spektakl był już w całości realizowany w muzeum, zaś w role wcieliły się dzieci z jednej z lubelskich szkół podstawowych. Sztuka składa się z pięciu aktów, występuje w niej dziewięć postaci oraz „Osobistości-Przedmioty”.

3 Por. G. Miliszkiewicz, Niechże historia chwali codzienność! Możliwe spektrum tematyczne wspótczesnej oferty edukacyjnej w muzeum na otwartym powietrzu, [w:] Muzea skansenowskie we wspótczesnej edukacji historycznej, red. M. Ausz, G. Miliszkiewicz, H. Stachyra, D. Szewczuk, Lublin 20II, s. 43-60. 
Głównym motywem są działania grupy bohaterów, którzy starają się pozyskać kowadło niezbędne do tego, aby Maciek - chłopski syn - mógł zostać czeladnikiem u kowala. Obok młodego chłopca postaciami w sztuce-baśni są jego rodzice, dziadek, kowal, żona kowala oraz trzej Żydzi - kupiec prowadzący sklep żelazny, domokrążca oraz dzierżawca sadów. Głos zabierają także dwa kowadła i żeliwny garnek. Wszyscy pomagają Maćkowi zdobyć upragniony przedmiot. Zaangażowani w spektakl goście wędrują po terenie skansenu. Konwencja literacka i realia muzeum pozwalają na przyswojenie wiedzy w sposób kompleksowy; stanowią - zdaniem G. Miliszkiewicza - skuteczną drogę do poznania wielu aspektów dawnego życia codziennego.

W części Kronika mUZealna Ewa Nakoneczna i Magdalena Łasisz - obie z MWR - dokonały bilansu aktywności i osiągnięć Muzeum na przestrzeni 20 lat (1997-2017) w ujęciu chronologicznym (a w jego ramach także tematycznym). Autorki uwzględniły aktywność Muzeum w dziewięciu obszarach: I. Zbiory i konserwacja, remonty i rozbudowa Muzeum; 2. Sesje naukowe, konferencje; 3. Badania naukowe; 4. Wystawy; 5. Frekwencja; 6. Wydawnictwa; 7. Działalność oświatowa; 8. Konkursy; 9. Nagrody, wyróżnienia. Z dokonanego tu zestawienia wynika, że w ciągu 20 lat radomskie muzeum na wolnym powietrzu wzbogaciło się o 22 obiekty architektoniczne. To nie tylko translokacje i rekonstrukcje tradycyjnego budownictwa wiejskiego, ale także inwestycje współczesne poprawiające w sposób zasadniczy infrastrukturę placówki - pawilony edukacyjno-ekspozycyjne, pracownia konserwatorska, amfiteatr, wieża widokowa itp. W tym czasie zorganizowano również niemal 300 wystaw czasowych, przeprowadzono ponad 6 tys. lekcji muzealnych.

Kronikę uzupełnia fotorelacja poprzedzona krótkim wprowadzaniem autorstwa Tomasza Dzikowskiego (MWR) poświęcona wybranym pracom konserwatorskim dokonanym w Muzeum w latach 2016-2018. Nadmieńmy, że Autor jest cenionym w środowisku muzealników wysokiej klasy specjalistą w dziedzinie konserwacji zabytków, wybitnym znawcą odpowiedzialnym za rozwój i opracowanie naukowe bogatej kolekcji autarkicznych maszyn rolniczych i ciągników SAM. Fotorelacja, którą prezentuje, poświęcona została w znacznej części dwóm poważnym zadaniom zrealizowanym przez MWR. Pierwszym było zakończenie prac konserwatorsko-remontowych w kościele pw. św. Doroty (świątynia już wcześniej została translokowana z Wolanowa) wraz z zakupem i montażem organów oraz wykonaniem i montażem kopii zabytkowych dzwonów na dzwonnicy z Wielgiego, natomiast drugim - translokacja wiatraka koźlaka z Wierzbicy położonego na terenie ekspozycji muzealnej. Przedstawiona 
dokumentacja ukazuje ogrom prac konserwatorskich wykonanych przy tych obiektach oraz ostateczny efekt tych działań.

Łamy jedenastego tomu „Wsi Radomskiej” udostępniono dla autorów zajmujących się problematyką wykraczającą poza Radomskie. Znalazły się tu materiały poświęcone sąsiednim regionom - Kielecczyźnie i Lubelszczyźnie, a także odleglejszemu Podlasiu. Nie zaniedbano jednak tematyki lokalnej za sprawą ciekawych artykułów biograficznych oraz rozległej kroniki MWR. Zawartość pisma zredagowano starannie, zadbano o różnorodną i czytelną ikonografię. Wypada życzyć redakcji stabilności wydawniczej oraz sukcesów w pozyskiwaniu autorów zasilających czasopismo wartościowymi tekstami. 